\title{
Geospatial Evaluation of Sustainable Development: Analysing a Sample of a Successful Social Safety Net
}

\author{
Giribabu Dandabathula ${ }^{1}$, Sudhakar Ch. Reddy ${ }^{2}$, Chandrika Mohapatra ${ }^{3} \&$ Peddineni V.V Prasada Rao ${ }^{4}$ \\ ${ }^{1}$ Regional Remote Sensing Centre - West, NRSC/ISRO, Jodhpur, India \\ ${ }^{2}$ Forestry and Ecology Division, National Remote Sensing Centre, ISRO, Hyderabad, India \\ ${ }^{3}$ Symbiosis Institute of Geoinformatics, Pune, India \\ ${ }^{4}$ Department of Environmental Sciences, Andhra University, Vishakhapatnam, India \\ Correspondence: D. Giribabu, Regional Remote Sensing centre - West, NRSC/ISRO, Sector 9, KBHB, Bypass \\ Road, Jodhpur-342005, Rajasthan, India. E-mail: dgb.isro@gmail.com
}

\author{
Received: May 8, $2019 \quad$ Accepted: June 3, $2019 \quad$ Online Published: June 20, 2019 \\ doi:10.5539/jsd.v12n4p1 URL: https://doi.org/10.5539/jsd.v12n4p1
}

\begin{abstract}
Sustainable Development (SD) not only ensures addressing the root cause of poverty but also helps in achieving the wellness of society. Protecting the natural resources for current and future generations is the main goal of the SD process. In recent times, developing countries have initiated social safety nets (SSNs) for poverty elimination and to achieve the SD goals through public works. The Government of India has initiated numerous development projects aimed to achieve SD and Mahatma Gandhi National Rural Employment Guarantee Act (MGNREGA) is one of them. The research objective of this article is to harness the power of geospatial technology for evaluating the public works under MGNREGA at a district level. The proposed research method utilizes the power of remote sensing data with a very high spatial and temporal resolution to monitor the development activities at the grass root level. Satellite based land-use maps, indices, and publicly available web based geospatial information systems have been used in this investigation to assess the changes that have occurred due to the community-level planned activities. The findings from this research confirm that MGNREGA has the potential to accrue multiple dividends at all the three pillars of SD, i.e., economic development, social development, and environmental protection. It was proved from this research that public works under MGNREGA besides providing the wage based employment to the beneficiaries resulted in improved water conservation and harvesting facilities in the study area and in return, these facilities acted as a catalyst for improved agricultural productivity.
\end{abstract}

Keywords: social safety nets, sustainable development, rural employment, rural development, water conservation and harvesting, MGNREGA, India

\section{Introduction}

The best era of human-kind is in progress after the United Nations' intervention to facilitate Sustainable Development (SD) and the unanimous adoption of Sustainable Development Goals (SDGs) by 193 countries. SD addresses the root cause of poverty, the needs of the society, and protection of the planet without destroying the resources needed for future generations. The 2030 agenda for SD points out that sustainability has three dimensions: economic, social, and environment (United Nations, 2015). Rockström and Sukhdev (2016) stressed that all SDGs are interrelated and categorized the 17 SDGs into 3 layers viz., the economy, the society, and the environment. Social Safety Nets (SSNs) are extended modules of the Governments' welfare measures that are gaining significance in today's quest for SDGs. SSNs will act as drivers of social protection and helps in achieving SDG 1. They can guarantee social justice, inclusiveness, strong democracies, and enables the economies and societies to survive from various kinds of crisis situations like economic shocks, natural disasters, and other unforeseen catastrophes. As of date, every developing country in the world has a SSN program (World Bank, 2017).

The impact of society on natural resources can give an indication in assessing the extent of SD (Devuyst, 2000; Singh, Murthy, Gupta, \& Dikshit, 2009). Impact on natural resources by society can be monitored by identifying those activities that will interact with ecosystem components. Earth Observation (EO) system gathers the information about the lithosphere, hydrosphere, biosphere, atmosphere, and their interactions using 
remote-sensing principles, supplemented by in-situ and survey data. Geospatial technologies embed a range of modern tools along with EO data, Global Position Systems (GPS), Geographic Information Systems (GIS), and the Internet to facilitate online mapping and analysis of the Earth and human societies (AAAS, 2018). The applications of geospatial technology has extended to many areas such as public transportation, environmental protection, natural resources management, planning and development activities, and disaster management (Raubal, 2018). Geospatial technology has helped people and economies around the globe to become healthier, safer, and better equipped to manage basic daily needs (Longley, Goodchild, Maguire, \& Rhind, 2005; Lautenbacher, 2006). Some researchers have speculated that Geospatial technology can become an important tool for a variety of analytical efforts in monitoring the SDGs (Campagna, 2005; Bello \& Aina, 2015).

From time to time and as a part of strategic governance, Indian Government implements various beneficial programmes for livelihood upliftment and has initiated numerous developmental projects aimed for SD. Primarily these schemes are for poverty alleviation, food security, employment generation, education, and to solve other pressing problems (Indian Planning Commission, 2007). The National Rural Employment Guarantee Act (NREGA), which has now been renamed to 'Mahatma Gandhi Rural Employment Guarantee Act (MGNREGA) was initiated in the year 2005 by the Government of India (GoI) aims at elevating the livelihood security of households in rural areas of the country. The scheme provides 100 days (150 days for marginal sections and at certain times during calamity conditions) in a given financial year of guaranteed wage employment to all adult members of the registered households who volunteer to do unskilled public works. Studies conducted by Desai, Vashishtha, \& Joshi (2015) shows that due to MGNREGA there is a poverty reduction overall by 32 per cent and has helped 14 million people from falling into poverty. Giribabu, Mohapatra, Reddy, \& Prasada Rao (2019) correlated the phenomenon of MGNREGA with SDGs and summarised that the MGNREGA helps in the process of reducing poverty, protecting the environment, and ensures that all people enjoy peace and prosperity.

This paper emphasizes the use of geospatial technology for monitoring the community level development works and synthesizes the yield of SD at a district level. The study has harnessed the transparency provisions provided by using ICTs to retrieve the information about the assets (infrastructure at rural communities and household level) that are developed under MGNREGA program. This article relies on logic that the economy gives necessary thrust to the society so that it progresses well within the sphere of the environment, and hence proactive conservation of natural resources.

\section{Literature Review}

\subsection{MGNREGA as a Successful Social Safety Net and its Spillover Benefits to the Natural Resources}

SSN programs are non-contributory assistance provided to the society and can be broadly categorised as cash transfers (conditional and unconditional), school feeding programs and education interventions, social pensions, health interventions, food and in-kind transfers, fee weavers and targeted subsidies, employment opportunities through public works, and other emergency/strategic interventions (Grosh, Del Ninno, Tesliuc, \& Ouerghi, 2008; Beegle, Coudouel, \& Monsalve, 2017). MGNREGA is categorized as public works type of SSN and is regarded as the largest program in human history in terms of providing employment, outreach, cost, beneficiaries, and extent of implementation (Subbarao, Del Ninno, Andrews, \& Rodríguez-Alas, 2012; World Bank, 2015; Maiorano, Das, \& Masiero, 2018).

In recent times, researchers have begun to assess MGNREGA spillover benefits focusing on environmental services, land, and water resources (Verma, \& Shah, 2012; Esteaves, Rao, Sinha, \& Roy, 2013; Ranaware, Das, , Kulkarni, \& Narayanan, 2015; Giribabu et al., 2019). Till now, approximately 41 million assets were built in the process of MGNREGA covering 691 districts of India. These assets were spread-out in 262585 rural clusters by more than 250 million of manpower and is still a continuous operational phenomenon (Dashboard, 2019). World Bank (2015) quoted that "creation of productive assets in rural areas through MGNREGA will yield significant long-term positive impacts in terms of Sustainable Development". The success factor of MGNREGA is that it abides by the locally evolved planning and development activities to manage natural resources sustainably and equitably.

The public works programs became popular development interventions due to their potential 'double dividend' of transferring wages to the poor while at the same time creating the public infrastructure (Gehrke, \& Hartwig, 2018). Public works with locally evolved norms linked with natural resource management like in MGNREGA will the yield third dividend in the form of nourishing the natural resources. Thus, there arises a win-win situation in this 'give and take' relation between the environment and society. The Environment will rejuvenate through the spillover benefits of MGNREGA's and society will be benefited by the way of durable rural assets. 
Figure 1 depicts the exchange of dividends between the three pillars of sustainability due programs like MGNREGA. SD can be produced when there is a balanced integration of environment, society, and economy; because, the economy is controlled by society and society is depended on the environment. There are 260 combinations of works which are permissible under MGNREGA, mostly these works are related to natural resource management, water facilitation works, agriculture-related, infrastructure development, rural connectivity and sanitation, and other allied activities (MGNREGA Guide, 2019).

\begin{tabular}{|c|c|c|}
\hline \multicolumn{2}{|c|}{ Society (as a subset to environment) } & \multirow{2}{*}{\begin{tabular}{|l|} 
Environment \\
$\begin{array}{l}\text { Livelihood sustainability from } \\
\text { environment to society }\end{array}$ \\
\end{tabular}} \\
\hline \multirow{2}{*}{\multicolumn{2}{|c|}{$\begin{array}{ll}\text { - Guaranteed job } & \text { - Improved productivity of aqua-culture } \\
\text { - Alternative income } & \text { - Improved socio-political relations } \\
\text { - Improves participatory approach } & \text { - Food security and affordable housing } \\
\text { - Women empowerment and focus on } & \text { - Facilitation of drinking water } \\
\text { vulnerable groups } & \text { - Drought proof, flood protection, and } \\
\text { - Skill enhancements } & \text { resistance from climate shocks } \\
\text { - Macro \& micro irrigation facilities } & \text { Improved dietary, education \& rural- } \\
\text { - Sustainable assets creation } & \text { urban connectivity } \\
\text { - Increased productivity of agriculture and } & \text { and etc.. } \\
\text { livestock } & \end{array}$}} & \\
\hline & & \begin{tabular}{|l|} 
Earth Observation (EO) systems will \\
help us in monitoring the land, water, \\
climate parameters, and overall \\
sustainable development by taking \\
advantage of interlinking nature of \\
environment, society and economy.
\end{tabular} \\
\hline \multirow{2}{*}{\multicolumn{2}{|c|}{ 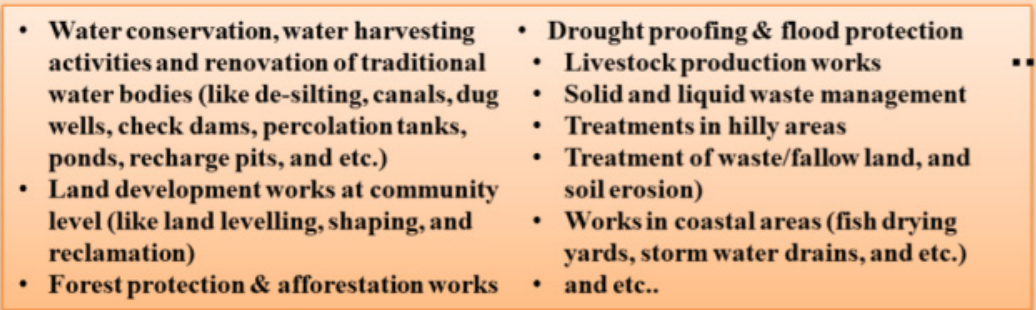 }} & \multirow{6}{*}{ 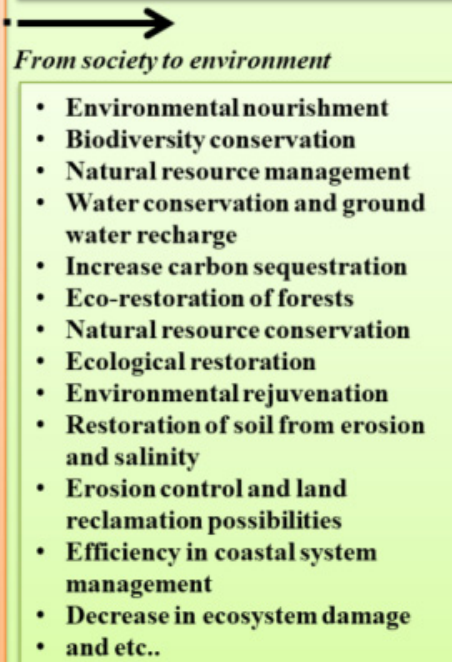 } \\
\hline & & \\
\hline \multirow{2}{*}{\multicolumn{2}{|c|}{ from economy to society $\mathbf{A} \quad$ from society to economy }} & \\
\hline & & \\
\hline $\begin{array}{l}\text { Federal funding in the form of public } \\
\text { works type of social safety net } \\
\text { (intervention for poverty) }\end{array}$ & $\begin{array}{ll}\text { - } & \text { Reduced poverty } \\
\text { - } & \text { Increased rural consumption/ec } \\
\text { - } & \text { Affirmative to GDP }\end{array}$ & \\
\hline & $\begin{array}{l}\text { Tolerance to economic shocks } \\
\text { - Resistivity against inflation } \\
\text { - Enhal economy improvement } \\
\text { - and etc.. }\end{array}$ & \\
\hline
\end{tabular}

Figure 1. A depiction of interactions between the three pillars of Sustainable Development due to the interventions like public works on natural resource

\subsection{Transparency of Information in MGNREGA}

ICT was identified as a tool that would enable the transparency in the process of MGNREGA due to the large size of the programme, geographical extent, financial implication, beneficiaries, and stakeholders. ICT ensures transparency and helps in information dissemination, facilitates online monitoring and evaluation of the programme (Reddy, 2013). A dedicated web portal exists for the social reporting of project proceedings and to support the 'Right to Information' act. The portal provides concise information about the active works, completed works, and progress of assets. The backend management information system (MIS) facilitates reporting of benefits accrued in the NREGA program (NREGA Web Portal, 2019). The geo-tagged assets have been put in the public domain under a portal titled GeoMGNREGA which is built on Bhuvan platform developed by Indian Space Research Organisation's (ISRO). Bhuvan provides necessary online geospatial support to MGNREGA project through an integrated view of asset information. In GeoMGNREGA, there are provisions to visualize assets at the state level, district level and sub-district level. Assets can be visualized based on the work category. The dashboard available at GeoMGNREGA provides statistical records of the Geo-tagged assets (MGNREGA Dashboard, 2018; GeoMGNREGA Dashboard, 2018; ISRO, 2016). Figure 2 represents the glimpse of Geo-portal which disseminates geo-tagged asset information to the public under MGNREGA project. 


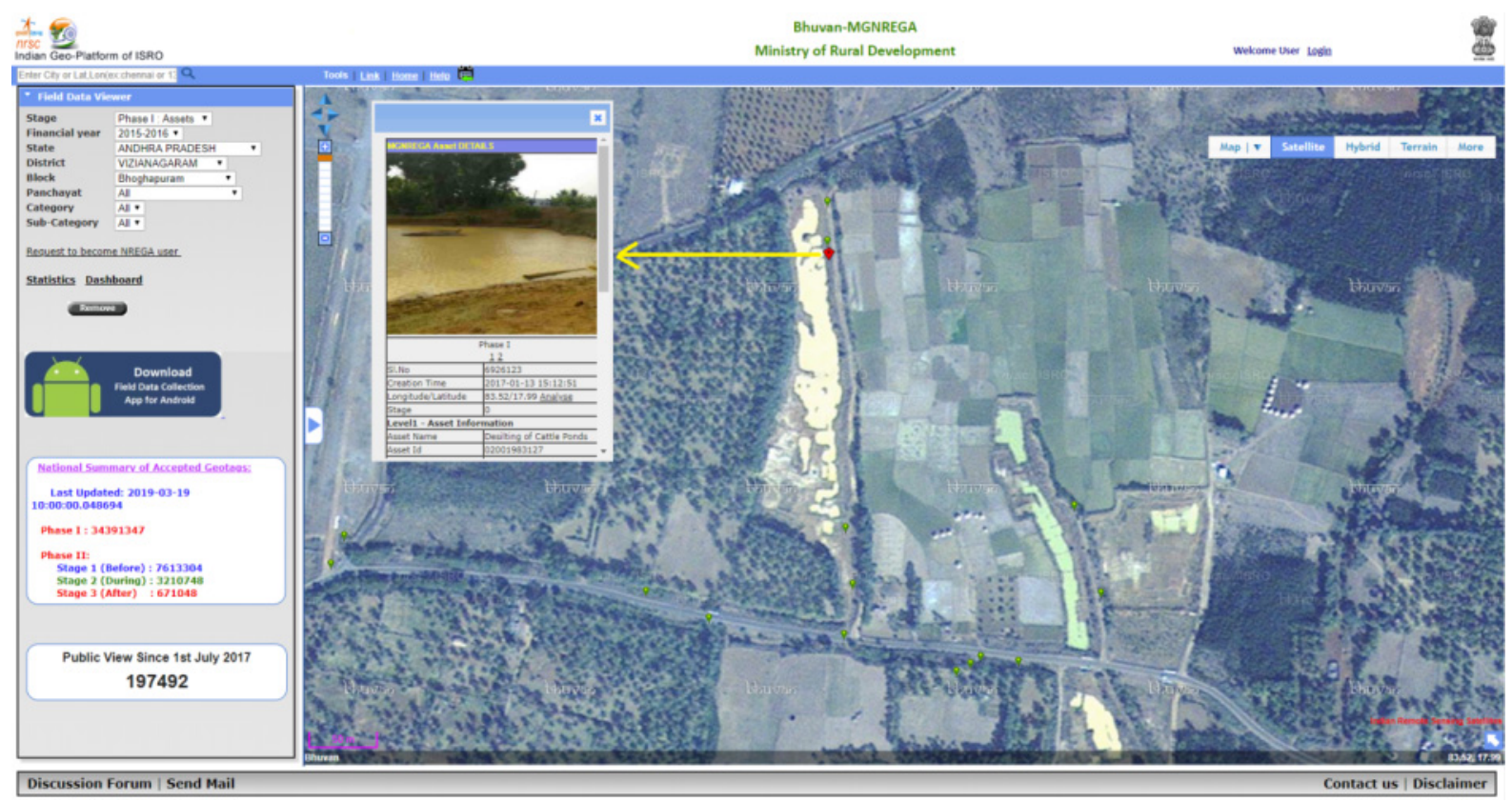

Figure 2. A screenshot of GeoMGNREGA web-portal, which facilitates the MGNREGA with evidence of a geo-tagged photograph of the asset. (Citizen view mode from GeoMGNREGA web portal)

\section{Study Area}

MGNREGA implementation is for the entire country with the sole exception of the urban population. Literature collected by Bose (2017) mentions that MGNREGA was rolled out in three different phases. Phase I was first implemented in 2006 in the 200 poorest districts in India. These districts were specifically targeted by the Planning Commission of India based on their backward status of Indian districts. This article focuses on Vizianagaram district which was recognised as a poorest district before MGNREGA implementation. Vizianagaram district falls in the legislative state of Andhra Pradesh.

Literature study from the articles dated pre-MGNREGA era i.e. before 2005 reveals that the Vizianagaram district is in need of special attention for development in many sectors. Composite indices for development in respect to agriculture, infrastructure and overall socio-economic sectors with respect to Vizianagaram district shows deteriorated ranking (Narain, Rai, \& Bhatia, 1999). Rao (2014) in his research found that between the years 1995 and 2001, most of the districts in Andhra Pradesh state are exhibiting socio-economic advancements but not Vizianagaram district. Reddy, Nalatwadmath, \& Krishnan (2005) reported that Vizianagaram district is in the zone of severe soil loss and the severity exceeds the tolerance limit and mentioned the requirement of soil and water conservation measures. The land capability of Vizianagaram district falls in the zone of problems with drainage, wetness, overflow, salinity/sodicity, gravel-illness, and water erosion. Nayyar (2005) in his report mentioned that Vizianagaram district is in the place where programmes and policies with the joint efforts of the federal and states government could remove barriers to growth, accelerate the development process and improve the quality of living standards.

The study area is a part of the Northern coastal plains of Andhra Pradesh state and lies between $17^{\circ} 15^{\prime}$ and $19^{\circ} 15^{\prime}$ of the Northern Latitudes and $83^{\circ} 0$ ' to $83^{\circ} 45^{\prime}$ of the Eastern Longitudes. The South-East of this district is bounded by the Bay of Bengal. Vizianagaram district is predominantly an agricultural district as $68.4 \%$ of the workers are engaged in agriculture and about $82 \%$ of the population of the district lives in the rural area. Paddy crop is cultivated mainly during Kharif season (Raju, 2015). As per Census 2011, population is 2344 474. Out of which males and females were 1161477 and 1182997 respectively. The total geographic area of the district is 653900 Hectares. Detailed profile of the study area is mentioned at (Vizianagaram Details, 2017). Figure 3 shows the geographical position of the study area in India. 


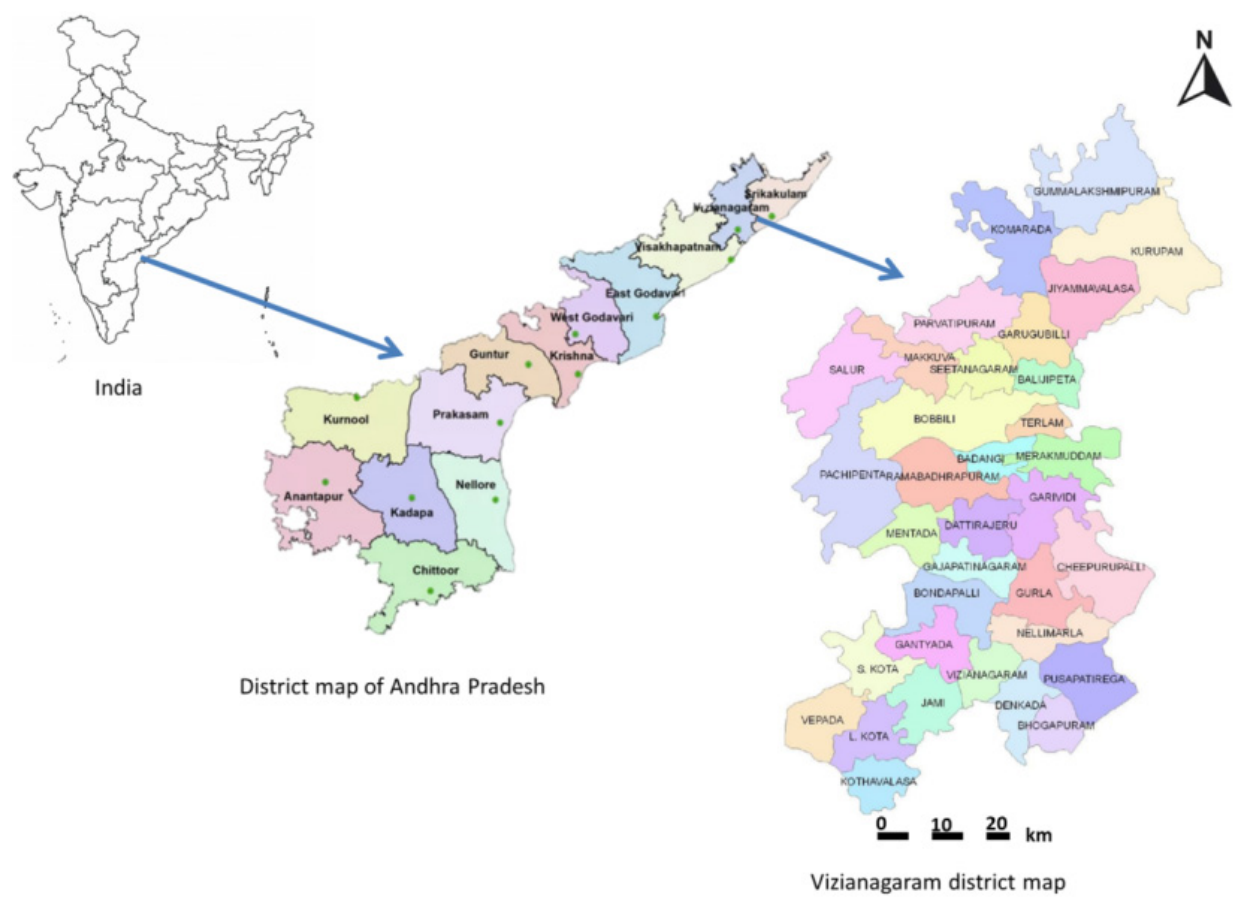

Figure 3. Vizianagaram district in Andhra Pradesh State, India

\section{Material and Methods}

\subsection{Geospatial Evaluators of Sustainable Development - Sensing the Environmental Pillar of Sustainability}

EO systems enable capturing the data from space, storing/archiving, managing and disseminating remotely sensed data via web-based GIS. The recent trend of EO technology has the capacity to improve the living standards of human beings, development of social economy, and contribution to the SDGs (Paganini, \& Petiteville, 2018). EO satellites obtains Very High Spatial Resolution (VHSR) images that are extensively exploited to produce land cover maps to deal with agricultural, ecological, and socio-economic issues as well as assessing ecosystems status, monitoring biodiversity and provide inputs to social problems (Gaetano, Ienco, Ose, \& Cresson, 2018). Visual interpretation of high-resolution Remote Sensing (RS) data will able to detect activities like rural connectivity (new roads), rural sanitation facilities (toilets), irrigation works, drought proofing works like afforestation and tree plantation activities, land development activities, water conservation, and harvesting activities. One of the derivable from EO data is the land use and land cover (LULC) change map which can be generated at stipulated intervals, will not only essay the general view of land cover changes, but also can best serve as a planning, monitoring, and evaluation tool. Table 1 shows some of the activities of MGNREGA that interact with the environment, and also the geospatial evaluator of the interaction. 
Table 1. Public works of MGNREGA that interact with natural resources and related geospatial evaluator

\begin{tabular}{|c|c|c|}
\hline $\begin{array}{l}\text { Activity under public works of } \\
\text { MGNREGA }\end{array}$ & $\begin{array}{l}\text { Interaction with Natural } \\
\text { Resources }\end{array}$ & Geosp \\
\hline $\begin{array}{l}\text { Works related to water } \\
\text { conservation and water harvesting. } \\
\text { (Construction of check dams, stop dam, } \\
\text { boulder check, underground dyke, farm } \\
\text { bunds, earthen dam, mini percolation } \\
\text { tanks, sub surface dam, sunken pond, } \\
\text { water absorption trench, and etc.) } \\
\text { - Watershed management works. } \\
\text { (Construction of contour trench, } \\
\text { contour bund, terracing, boulder check, } \\
\text { gabion structures, sunken pond, } \\
\text { spring-shed treatment, and etc.) } \\
\text { - Renovation of traditional water } \\
\text { bodies. } \\
\text { (De-silting of the water-bodies, } \\
\text { removing/cleaning of encroachments, } \\
\text { removal of aquatic weeds, and etc.) }\end{array}$ & 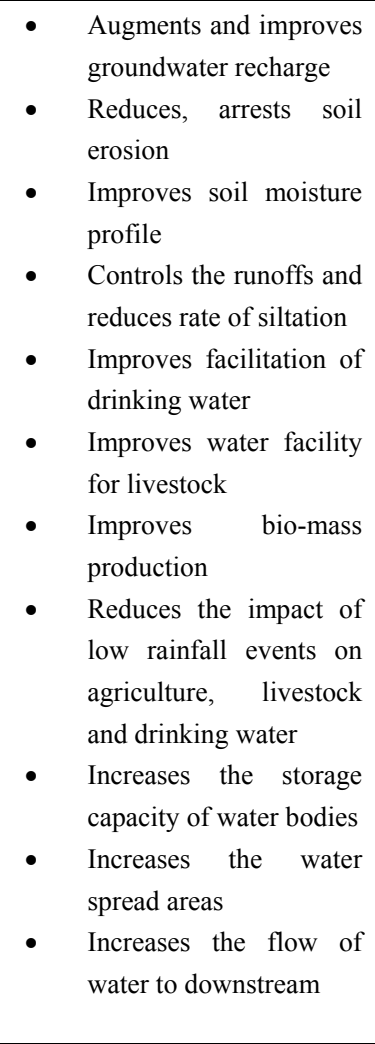 & $\begin{array}{l}\text { - During the construction phase these activities } \\
\text { can be monitored using high resolution satellite } \\
\text { data. Geoportals will enable to upload } \\
\text { geo-tagged photographs during the construction } \\
\text { from the field, and in turn will provide status of } \\
\text { the work } \\
\text { - The effects of water conservation and water } \\
\text { harvesting structures on groundwater recharge } \\
\text { and soil erosion can be studies using RS } \\
\text { methods } \\
\text { Soil erosion studies can be done using RS } \\
\text { methods. Microwave RS studies have proven to } \\
\text { be predicting realistic estimations of soil } \\
\text { moisture } \\
\text { The effects of soil moisture can be correlated } \\
\text { with vegetation growth and hence this } \\
\text { phenomenon can be monitored using NDVI } \\
\text { techniques } \\
\text { National Remote Sensing Centre (NRSC) } \\
\text { monitors the status of all water bodies (nearly } \\
\text { two lakh in count) in the country using } \\
\text { multi-resolution satellite images. The estimated } \\
\text { water spread area on the date of image is } \\
\text { published in dedicated Water Body Information } \\
\text { System (WBIS, 2019) }\end{array}$ \\
\hline $\begin{array}{l}\text { Construction and renovation of micro and } \\
\text { minor irrigation works (like canals, } \\
\text { distributary and minor routing canals, } \\
\text { lining of canals, correction of water } \\
\text { conveyance system, correction of system } \\
\text { deficiencies about outlet upto } \\
\text { distributaries, and etc.) }\end{array}$ & $\begin{array}{l}\text { - Facilitates water to } \\
\text { agriculture purpose. } \\
\text { Reduces the impact of } \\
\text { low rainfall events on } \\
\text { the agriculture }\end{array}$ & $\begin{array}{l}\text { - Before and during the construction phase these } \\
\text { activities can be monitored using high resolution } \\
\text { satellite data. } \\
\text { - Studies related to water stress on agriculture can } \\
\text { be done using RS }\end{array}$ \\
\hline $\begin{array}{l}\text { Drought proofing works. Examples } \\
\text { include eco-restoration of forest, } \\
\text { reforestation, tree plantation, block } \\
\text { plantation, avenue plantation, } \\
\text { afforestation, grass land development, } \\
\text { bio-drainage, plantation in government } \\
\text { lands, and etc. }\end{array}$ & $\begin{array}{l}\text { Local natural and human } \\
\text { production resource base } \\
\text { should able to provide a certain } \\
\text { desirable amount of food, fuel, } \\
\text { fodder, drinking water and } \\
\text { livelihood resources during a } \\
\text { drought }\end{array}$ & $\begin{array}{l}\text { - Impacts of these studies can be done using RS } \\
\text { indices along with drought prediction models } \\
\text { - Studies related to eco-restoration of forest, } \\
\text { afforestation, grass land development can be } \\
\text { done using RS data along with socio-economic } \\
\text { data }\end{array}$ \\
\hline $\begin{array}{l}\text { Springshed development (in mountain } \\
\text { regions) like trenching, planting of trees, } \\
\text { fodder grasses or hedges and gull } \\
\text { plugging. }\end{array}$ & $\begin{array}{l}\text { To create source of water } \\
\text { supply systems, enhance } \\
\text { rainfall infiltration, recharge } \\
\text { springs, revive dysfunctional } \\
\text { traditional water harvesting } \\
\text { systems. }\end{array}$ & $\begin{array}{l}\text { - In the mountainous regions, most of the } \\
\text { consumable water originates from springs. The } \\
\text { uncertainty can be monitored using RS methods } \\
\text { along with digital elevation models } \\
\text { - Climatic factors, anthropogenic causes and the } \\
\text { topography, vegetation cover, soil and geology } \\
\text { of an area also affects the water availability in a } \\
\text { region. These factors control the rainfall runoff } \\
\text { and groundwater recharge and storage. Hence } \\
\text { RS data can be used to monitor springshed } \\
\text { management along with other in-situ data. }\end{array}$ \\
\hline
\end{tabular}


- Construction of Poultry shelter, goat shelter, fodder trough

- Construction of buildings (like houses, food grain storage and etc.,)
- Accrue of community level infrastructure

- Housing facility for marginal and vulnerable groups and etc.,

- $\quad$ Food storage, security and other need based infrastructure

\begin{tabular}{|c|c|c|}
\hline $\begin{array}{l}\text { (tanks, water harvesting ponds, } \\
\text { ing of the bed and fish drying }\end{array}$ & $\begin{array}{l}\text { s in boosting fisheries } \\
\text { pation. }\end{array}$ & $\begin{array}{l}\text { Can be monitored using RS data with high resolution and } \\
\text { multi resolution data for coastal area development } \\
\text { applications }\end{array}$ \\
\hline $\begin{array}{l}\text { Rural drinking water (soak pits, recharge } \\
\text { pits), rural sanitation, solid and liquid } \\
\text { waste management, flood management } \\
\text { related, irrigation related (like canal, } \\
\text { channel) }\end{array}$ & $\begin{array}{l}\text { solve drinking water } \\
\text { blems, facilitate irrigation } \\
\text { ilities, and control the flood } \\
\text { e events. }\end{array}$ & $\begin{array}{l}\text { ution RS data. Water } \\
\text { pped in RS data using }\end{array}$ \\
\hline $\begin{array}{l}\text { Pro-forest activities like tree plantation, } \\
\text { grass lands, nursery, afforestation } \\
\text { activities, and etc. }\end{array}$ & 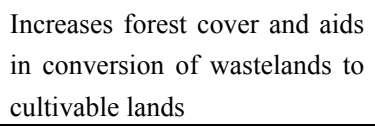 & $\begin{array}{l}n \text { be mapped using RS data. Portal titled Global Forest } \\
\text { atch can be used to monitor the forest lost and gain } \\
\text { ents. }\end{array}$ \\
\hline
\end{tabular}

Can be seen in high resolution RS data using change detection techniques. Information systems will able to accumulate the filed photographs using controlled crowd sourcing methods

Allen (1999) mentioned that community food security efforts are important additions for SSNs. Hence monitoring the food security efforts or agriculture activities is one of the important indicators for evaluating SSNs. Land development works, drought proofing activities, soil conservation methods, and irrigation facilitation will result in improved agriculture productivity. Towards this, the measurement of vegetation signatures using RS sources has become a critical way to measure the effects of regional and global-scale agricultural production. The most common method for this is the Normalized Difference Vegetation Index (NDVI) technique. NDVI represents the effects of climate and water on vegetation in terms of its absorptive capacity in visible light but little in the near-infrared spectrum. The difference between visible and near-infrared reflectance represents photosynthetically active vegetation; this information is used to construct a vegetation index. The lower value of the vegetation index indicates moisture stress in vegetation, resulting from prolonged water deficiency. Higher NDVI values might reflect ideal growing conditions if vegetation greenness is higher than that encountered in other years. MaximumNDVI or MaxNDVI gives the maximum NDVI value of the growing season and represents peak vegetation photosynthetic activity. MaxNDVI gives the trend of vegetation health for the studies which span over some years (Burgan, \& Hartford, 1993; Bhatt et al., 2017).

Modern RS and GIS techniques are very useful for water resources management and conservation plans (Shakoor, Shehzad, \& Asghar, 2006). Satellite-based Water Body Information Systems (WBIS) provides timely information about the water spread area and other derived information. Usual forms of water bodies are canals, rivers, lakes, aquaculture/pisciculture (natural/man-made) based water bodies, reservoirs, ponds, irrigation facilities (like wells, tanks, and etc.) (WBIS, 2019). Most of the water from the water bodies is primarily used for agriculture, drinking water, cottage industries, and livestock production purposes in the rural areas.

The Rural population usually draw upon the outputs of trees and forest in their vicinity for various reasons like direct use by the household, such as fuel and food; inputs into the agricultural system, such as fodder and mulch; sources of income and employment (Wackernagel, \& Rees, 1998). Soil conservation works, afforestation, tree plantation, boundary plantation, agro-forestry, block plantation, and agro horticulture works includes in the agenda of this SSN, they have positive impacts on the forest conservation by directly giving sufficient purchasing power and reducing the dependency on forest resources. Hence forest area monitoring gives an indication of the dependency of the peri-rural population on the forest. Figure 4 depicts the forest theme based web-GIS portal based called 'Global Forest Watch'. These kinds of portals are highly useful to monitor the changes in the forest areas. 


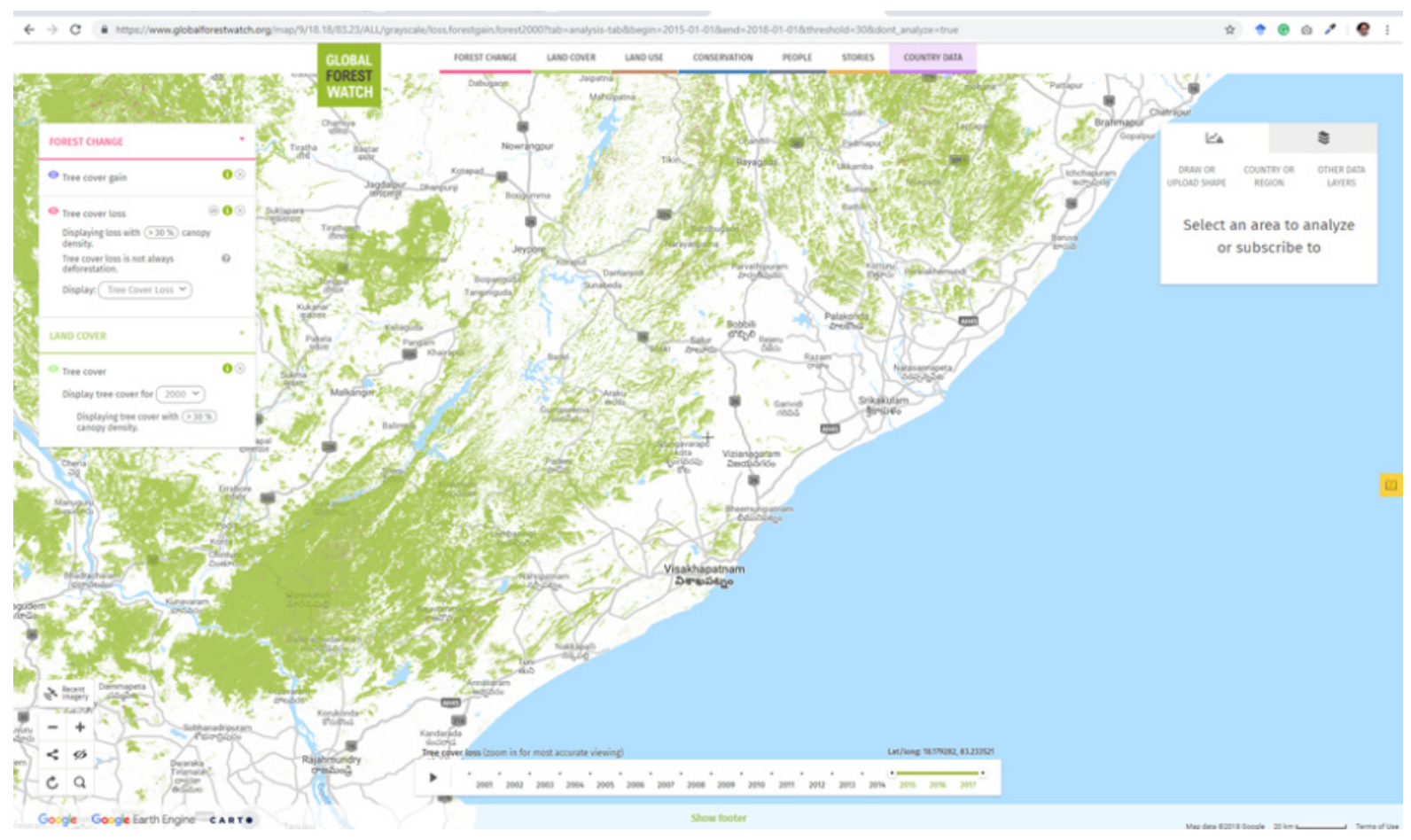

Figure 4. A screenshot showing Vizianagaram and surroundings in Global Forest Watch geo-portal

\subsection{Methodology}

Figure 5 depicts the methodology used in the evaluation of assessing sustainable development at the environmental pillar of sustainable development using geospatial evaluators and agriculture output parameters as validators. Details about the durable assets that are created in MGNREGA program were taken from GeoMGNREGA portal (in citizen mode) which gives the information in the tabular format as well as in spatial domain along with the evidence of field photographs. The location of the geo-tagged asset helps in deriving the hotspots of activities carried under MGNREGA.

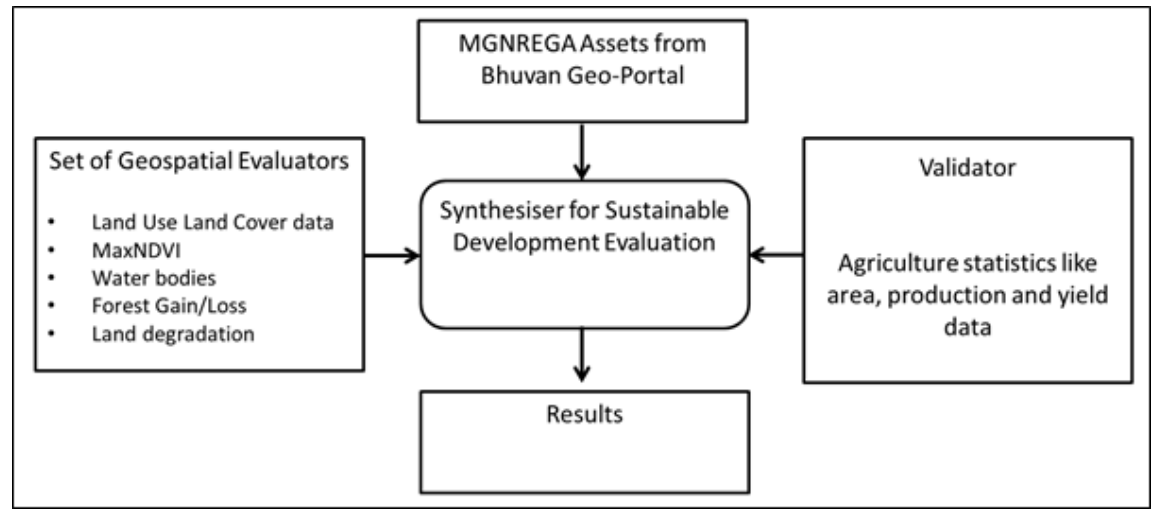

Figure 5. Methodology for rapid evaluation of sustainable development using Geospatial evaluators and agriculture outputs parameters as validators

The following section gives the information pertaining to the geospatial evaluators that are used in the methodology.

- Landuse and Land Cover (LULC) maps at 1:10k scale were generated from Indian Remote Sensing (IRS) ResouceSat-1/2 LiSS IV data for the years 2009, 2011, 2013 and 2015. 
- Maximum of NDVI (MaxNDVI) has been derived at agriculture fields from the RS imagery from the year 2009-2016 during cropping seasons, where the density of the assets is quite significant and appears to be a hotspot.

- Analysis of water bodies was carried out in the study area from the year 2012 till 2015 to check for the evidence of changes due to water harvesting and water conservation activity which has contributed for improved ground water levels and increased water availability for irrigation.

- Land degradation maps were generated for the years 2009 and 2015.

- The forest loss/gain was used as an indicator to assess the forestry component from global forest watch geo-portal.

A semi-automatic synthesizer has been developed to derive the results. The synthesizer will ingest the geospatial evaluators, the spatial distribution of assets (hot spots based on the category of work), and evaluates the impact of public works by correlating with the indicators. Agriculture production and yield information were taken from the reports available from online web portal maintained by Directorate of Economics and Statistics of Andhra Pradesh state government (DESAP, 2018).

\subsection{Rationale for Using Agriculture Statistics like Area, Production and Yield Data as a Validator}

Basiago (1999) in his studies mentioned that cultural practices and food should be a part of the policies for development to achieve sustainability. Odum (2007) reported that energy from the community efforts goes to our environment system to increase the yield of food and food security. Sage (2011) mentioned that a sustainable food system is committed to the principle of social justice, which means working to ensure the availability of food. The works from (Rockström, \& Sukhdev, 2016) mentions that the economies and societies are embedded parts of the biosphere and in that food has as a pivotal role that connects all this three-layers. Hence as this part of the study region is a purely agrarian cult, the agriculture output as validator best describes sustainability.

\section{Results}

Public works under MGNREGA have progressed well in all the 34 sub-districts of the Vizianagaram district. Dashboard (2019) mentions that a total number of 934 village clusters have actively participated in this program. A total of 10.84 Lakhs workers were involved in MGNREGA program in this district. The study area contains more than 430000 assets over an area of $653900 \mathrm{Ha}$ of land. Table 2 depicts the total number of assets developed from the year 2009 till 2018. It is obvious that predominantly the assets were for irrigation, water conservation, water harvesting, and drought proofing works. From the year 2017 and 2018, there is demand and increase in rural sanitation works in the study area.

Table 2. Year-wise MGNREGA assets details in the Vizianagaram District

\begin{tabular}{|c|c|c|}
\hline Year & No. of Assets & Dominant asset type \\
\hline $2009-10$ & 5646 & Irrigation works and water harvesting \\
\hline 2010-11 & 48535 & Water harvesting and Irrigation works \\
\hline 2011-12 & 69997 & Irrigation and water conservation works \\
\hline $2012-13$ & 26035 & Drought proofing and irrigation works \\
\hline 2013-14 & 37432 & $\begin{array}{l}\text { Drought proofing, water conservation works and land } \\
\text { development activities }\end{array}$ \\
\hline 2014-15 & 21661 & $\begin{array}{l}\text { Irrigation works, water conservation, water harvesting, renovation } \\
\text { of traditional water bodies and drought proofing works }\end{array}$ \\
\hline 2015-16 & 26838 & Drought proofing, plantation and irrigation works \\
\hline 2016-17 & 177114 & $\begin{array}{l}\text { Irrigation works, rural connectivity plantation and rural sanitation } \\
\text { works }\end{array}$ \\
\hline $2017-18$ & 58510 & $\begin{array}{l}\text { Irrigation works, drought proofing, rural connectivity and rural } \\
\text { sanitation works }\end{array}$ \\
\hline
\end{tabular}

Source: MGNREGA Dashboard 2018; GeoMGNREGA dashboard 2018 
Figure 6 depicts the LULC map for the year 2009, 2011, 2013 and 2015. On analyzing the temporal LULC maps it confirms that conversion of pockets of wastelands to agriculture practices. Figure 7 shows the MaxNDVI derived from the sampled areas at the hotspots that are having high intensity of land development activities, irrigation facilities and soil fertility improvement works. The MaxNDVI values over 215 samples show steep improvement in the vegetation in the study area. The values of MaxNDVI have increased from 0.55 to 0.64 over a span of 6 years. Approximately 182 water bodies in the study area were analysed. Figure 8 represents the screenshot of GeoMGNREGA portal to retrieve the hotspots information of the works done under MGNREGA. Figure 9 represents the category wise hotspots for various assets at sub-district level.
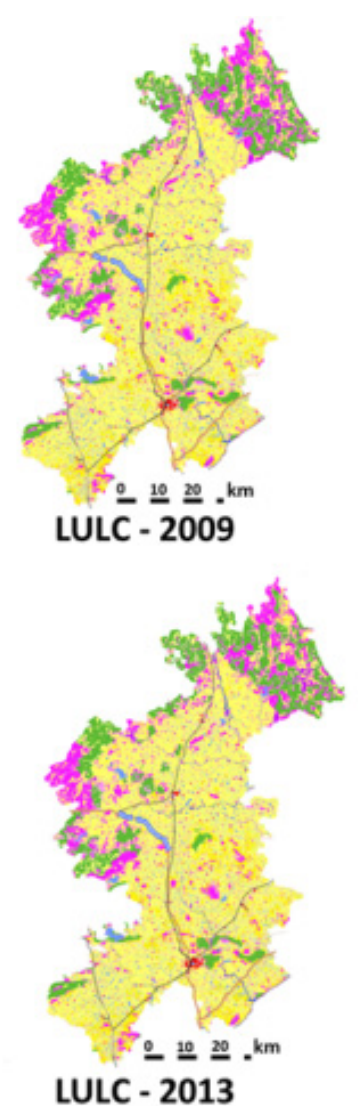
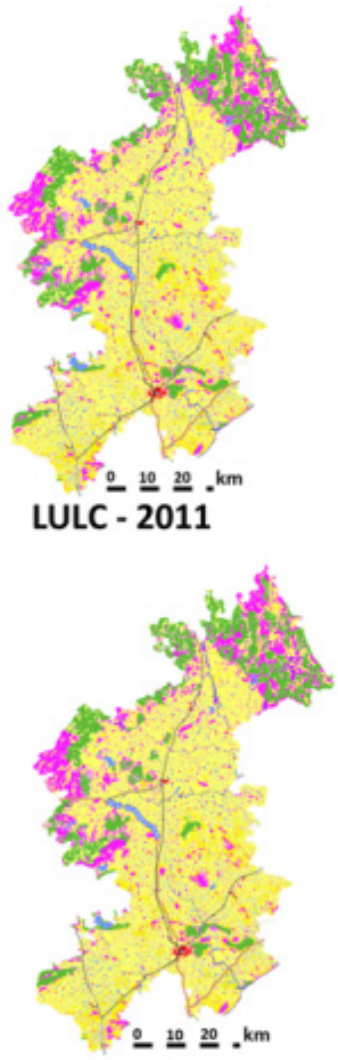

LULC - 2015
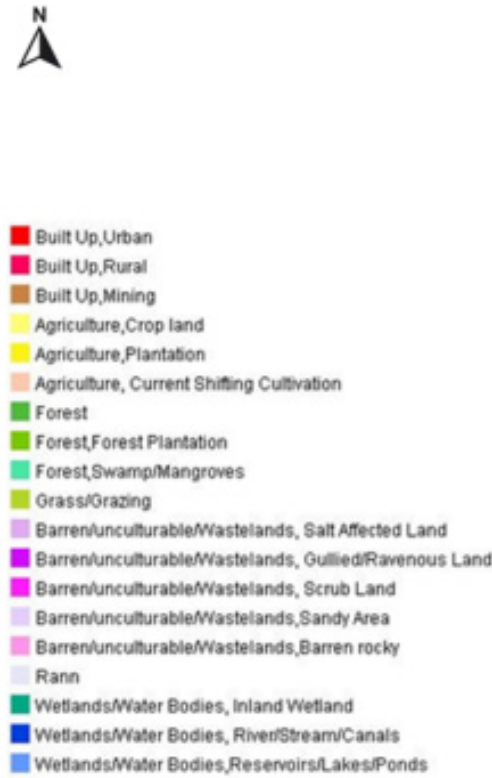

WettandsWater Bodies.Resenoirsl akes:Ponds

Figure 6. Land Use Land Cover (LULC) maps of Vizianagaram district for the years 2009, 2011, 2013 and 2015

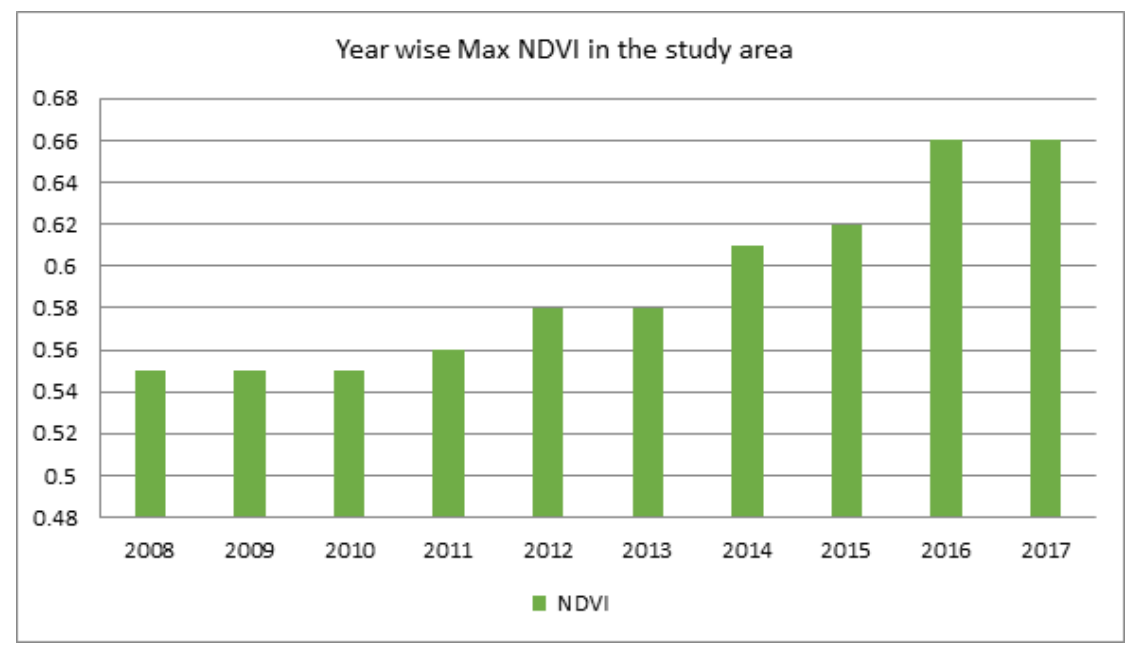

Figure 7. Chart depicting MaxNDVI at sample points from 2008 till 2015 


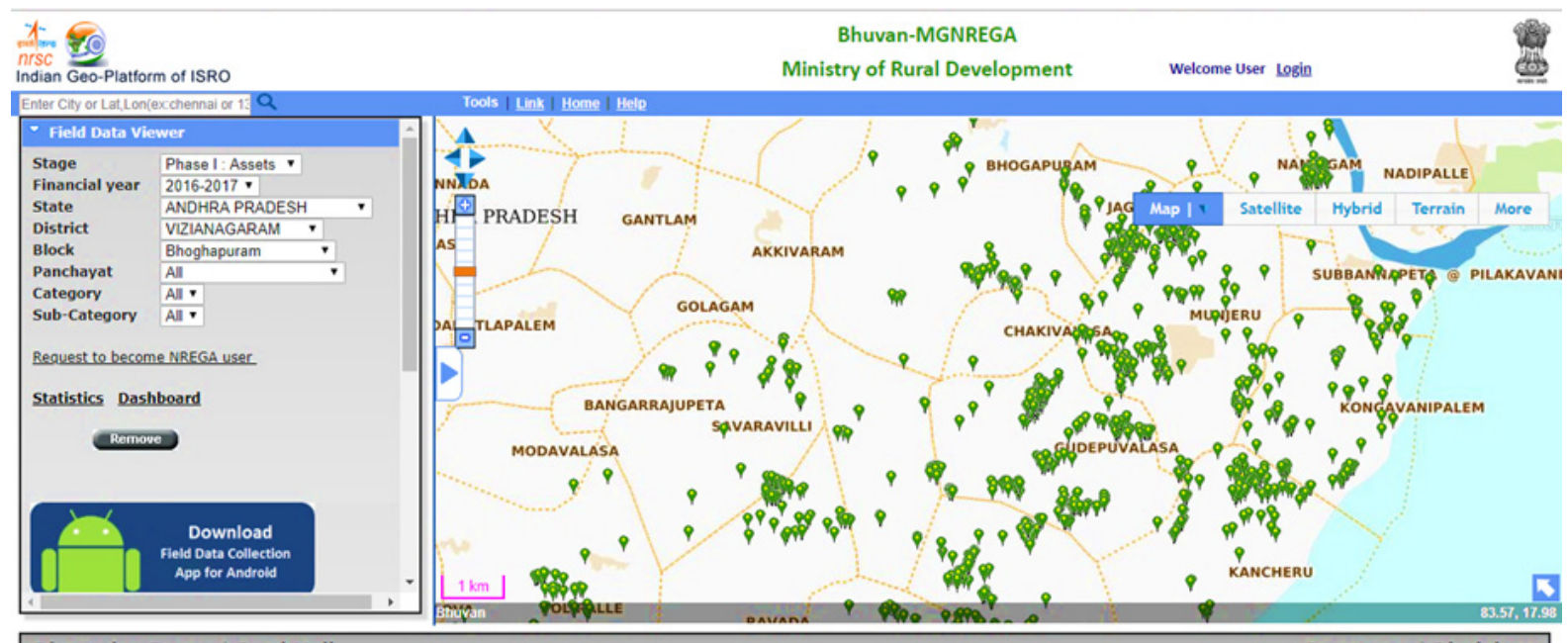

Figure 8. Spatial distribution of assets in the study area for the year 2016-2017 in sub-block Bhogapuram (figure captured in citizen view mode)

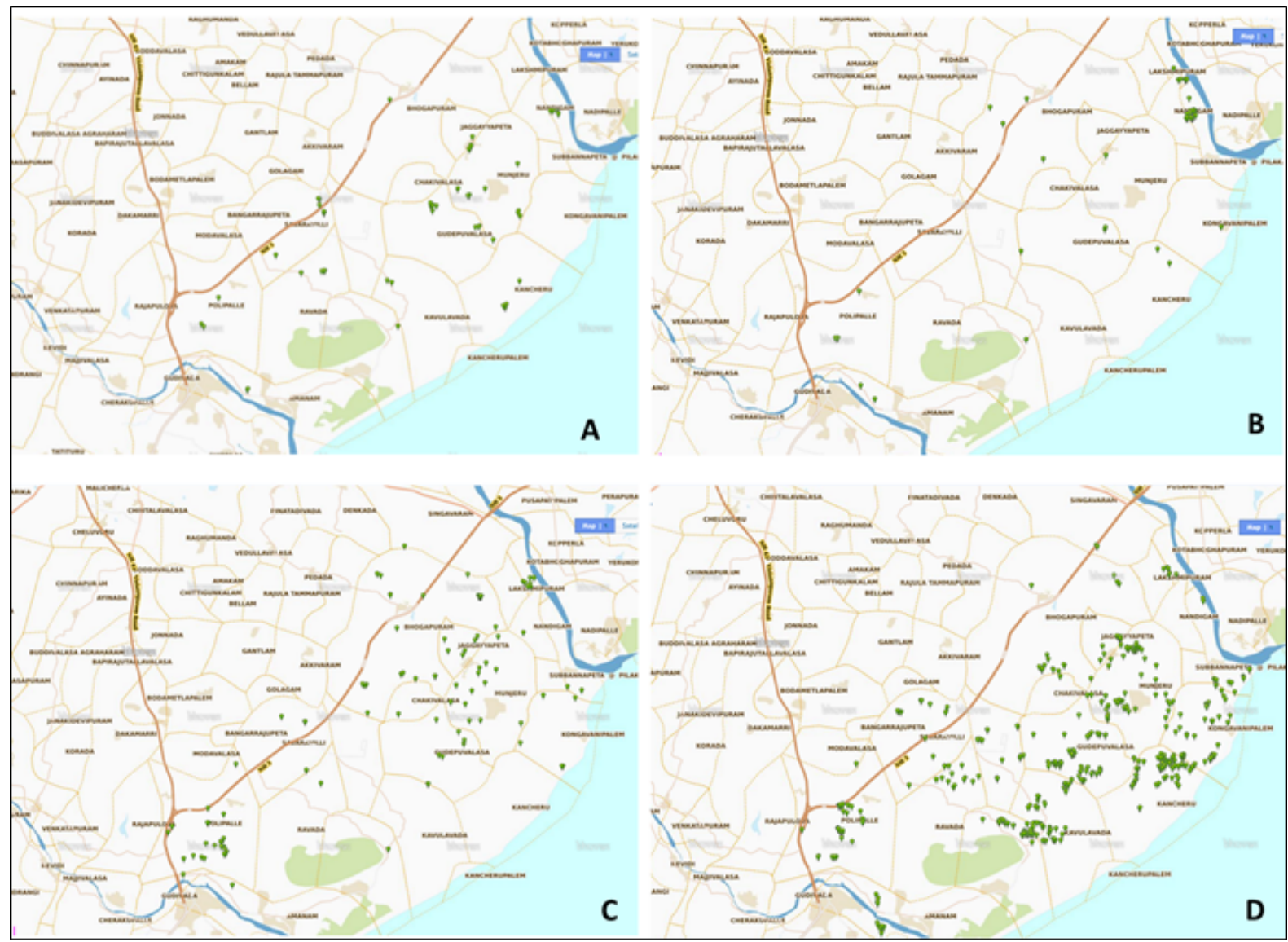

Figure 9. Hotspots of MGNREGA assets in Bhogapuram, a sub-district of Vizianagaram district. A - Assets pertaining to Rural drinking water work. B - Assets pertaining to Drought proofing. C - Renovation of traditional water bodies. $\mathrm{D}$ - Water conservation and water harvesting

Table 3 shows the results obtained for the study. It is observed that there is an improvement in terms of land development for agriculture productivity. Results also confirm that water harvesting activities have a positive 
impact in the study area for providing drinking water and irrigation facilities. The farmers, who used to face water crisis during drought, are now happy after digging the farm ponds in this region. The farm ponds helped in storing rainwater and gradually raised the groundwater level in surrounding areas. The required moisture for the fields is available throughout the year. Although farmers were aware of the concept, many were unable to implement the idea given the cost of digging ponds earlier, but through MGNREGA this was made possible. From the visual interpretation of high-resolution satellite data, there is evidence of improvement in the restoration of degraded and eroded lands.

Table 3. Observation of changes from the geospatial evaluators in Vizianagaram district from 2009 till 2015

\begin{tabular}{ll}
\hline Indicator & Observation \\
\hline $\begin{array}{l}\text { Satellite based LULC maps for the year } \\
2009,2011,2013 \text { and 2015. }\end{array}$ & $\begin{array}{l}\text { From the LULC derived through satellite data there is evidence of converting pockets of } \\
\text { wastelands regions into agriculture. }\end{array}$ \\
\hline MAX NDVI at peak cropping season. & $\begin{array}{l}\text { Max NDVI values over 215 sample points shows steep improvement in the vegetation. The } \\
\text { values NDVI has increased from } 0.55 \text { to } 0.64 \text { over the span of } 6 \text { years. }\end{array}$ \\
\hline Interpretation of Water bodies & $\begin{array}{l}\text { Approximately } 182 \text { water bodies in the study area where analyzed. The observation is that } \\
\text { majority of water bodies' exhibits excellent recharge and water spread area. }\end{array}$ \\
\hline Interpretation of Forest cover from Global & $\begin{array}{l}\text { There is no change in the forest cover. For the year } 2005 \text { the area of the forest cover is } 119 \\
\text { forest watch portal }\end{array}$ \\
\hline Land degradation and erosion & $\begin{array}{l}\text { Traces of improvement in land degradation and erosion were observed in the temporal } \\
\text { analysis of land degradation data. }\end{array}$ \\
\hline Agriculture Productivity & $\begin{array}{l}\text { From the statistics of agriculture productivity it is observed that there is significant increase } \\
\text { in total cropped area, net area irrigated (through canals and tanks). There is increase in total } \\
\text { area for food grain and also its productions. The area of principal crop (rice), production } \\
\text { and yield were also increased significantly. }\end{array}$ \\
\hline
\end{tabular}

Table 4 represents the agriculture statistics for the study from the year 2010 till 2016. The observation from this statistics shows that there is a significant increase in gross cropped area, net area irrigated (through canals and tanks). There is an increase in the total area for food grain and also its production. The area of the principal crop (rice), production and yield were also increased from 2009 to 2016. In 2009 the yield per hectare area is 2209 $\mathrm{kgs} / \mathrm{Ha}$ and the yield per hectare area is $3115 \mathrm{kgs} / \mathrm{Ha}$ in the year 2016. This clearly shows the yield has increased significantly within a span of 7 years. A total of 413258 assets acted as a catalyst for the sustainability and supported conservation of the ecosystem in the study area. All this besides the labour who contributed in these assets have got their wage in the form of alternative income.

Table 4. Agriculture statistics (2009 - 2017) for Vizianagaram district (agri-stat, 2010; agri-stat, 2011; agri-stat, 2012; agri-stat, 2013; agri-stat, 2014; agri-stat, 2015; agri-stat, 2016; ; agri-stat, 2017)

\begin{tabular}{|c|c|c|c|c|c|c|c|c|}
\hline Year & $\mathbf{A}$ & B & & & & & & \\
\hline $2009-2010$ & & 373 & 154 & 187 & 337 & 109 & 239 & 2209 \\
\hline $2010-2011$ & & 402 & 184 & 214 & 443 & 134 & 348 & 2611 \\
\hline 2011-2012 & & 379 & 179 & 189 & 385 & 125 & 268 & 2149 \\
\hline $2012-2013$ & & 373 & 184 & 193 & 444 & 126 & 321 & 2551 \\
\hline 2013-2014 & & 358 & 177 & 190 & 442 & 117 & 291 & 2491 \\
\hline 2014-2015 & & 373 & 186 & 197 & 514 & 125 & 332 & 2664 \\
\hline $2015-2016$ & & 372 & 188 & 208 & 773 & 126 & 360 & 2990 \\
\hline 2016-2017 & & 382 & 189 & 213 & 800 & 125 & 390 & 3115 \\
\hline \multicolumn{9}{|c|}{ A - Gross Cropped Area ('000 Ha) } \\
\hline \multicolumn{9}{|c|}{ B - Gross area irrigated (using Canal and Tanks) ('000 Ha) } \\
\hline \multicolumn{9}{|c|}{$\mathrm{C}$ - Gross area used for Food grains (two seasons) ('000 Ha’) } \\
\hline \multicolumn{9}{|c|}{ D - Production ('000 Tonnes') } \\
\hline \multicolumn{9}{|c|}{ E - Gross area used for principle crop (rice for two seasons) ('000 Ha') } \\
\hline \multicolumn{9}{|c|}{ F - Production of principle crop (rice) ('000 Tonnes’) } \\
\hline $\mathrm{G}-$ Yield o & le c & ce) $(\mathrm{kgs}$ pe & are) & & & & & \\
\hline
\end{tabular}


Numerous water restoration works were happened in MGNREGA project in Vizianagaram district. The results are evident in the VHSR remote sensing data, one example is shown in figure 10 where the restoration works have influenced the water spread area. Similarly figure 11 shows an area where sustainable land use pattern have prevailed due to land development activities.

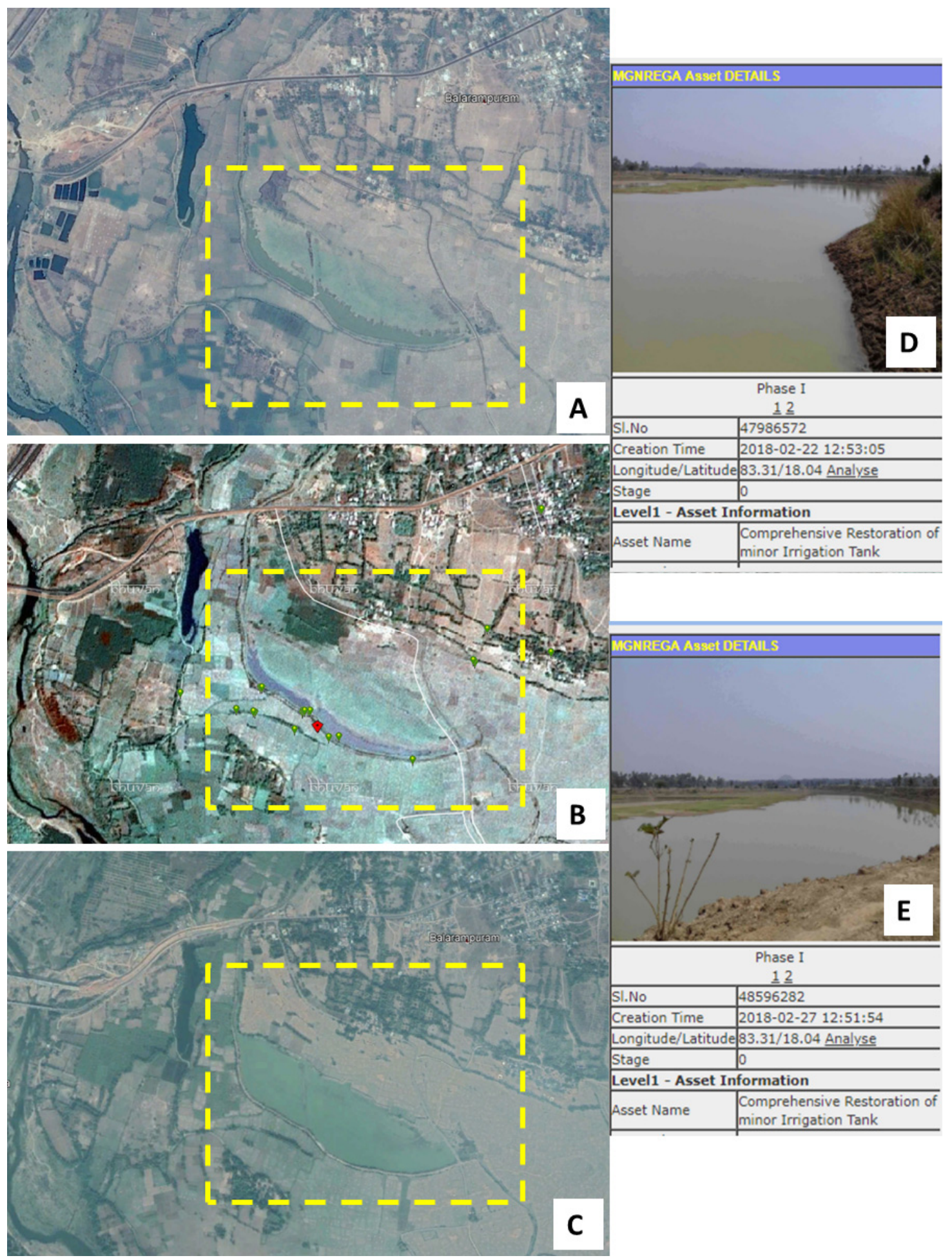

Figure 10. Restoration of minor irrigation tank through MGNREGA public work in Jami village in Vizianagaram

District. (A) Satellite data of date March 2011 showing the reservoir with less water spread area. (B)

GeoMGNREGA application showing details of assets at the reservoir. (C) Satellite data of date March 2017 showing the reservoir with more water spread area. (D) and (E) illustrates the geo-tagged photographs of the asset taken from two different angles 

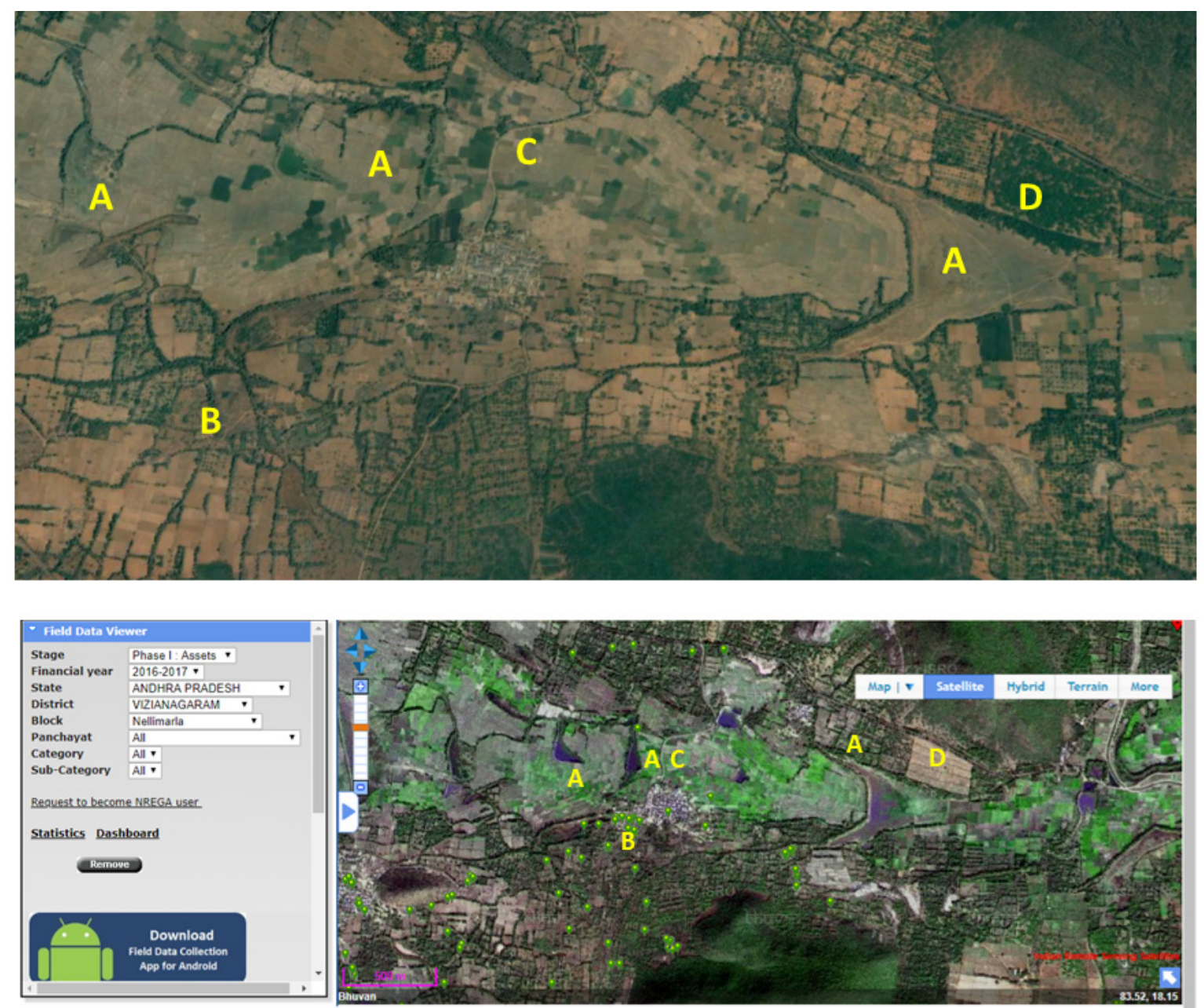

Discussion Forum | Send Mail

Contact us | Disclaimer

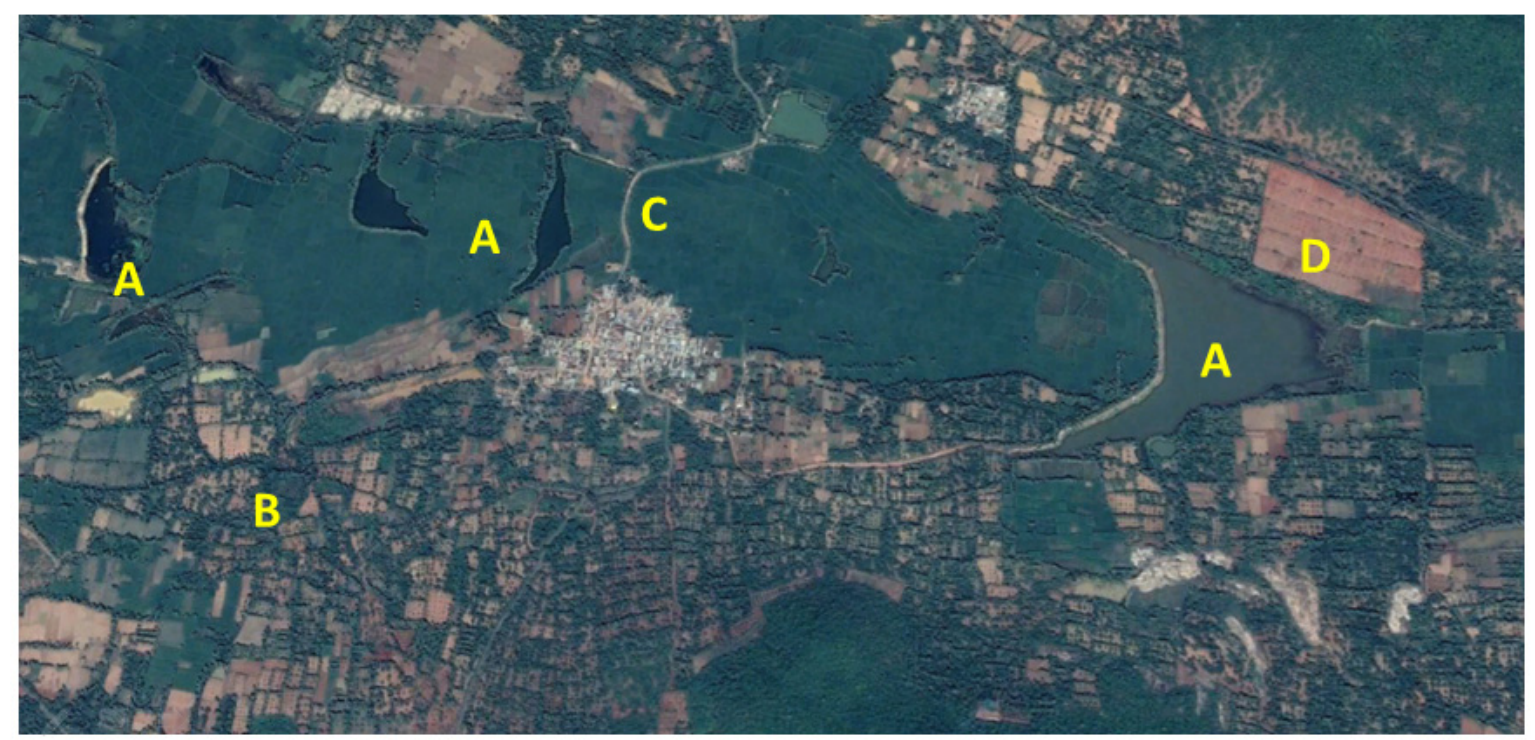

Figure 11. Sustainable development resulting in green revolution and blue revolution monitored through remote sensing data - Nellimarla village in Vizianagaram District. (Top) Satellite data of August 2008. (Middle) Assets during the year 2016-2017. (Down) Satellite data of August 2016. The area marked with: 'A' represents reclaiming of water bodies, ' $\mathrm{B}$ ' represents the conversion of wastelands to fodder production, ' $\mathrm{C}$ ' represents the effective use of land for the principal crop (rice), and ' $\mathrm{D}$ ' represents the conversion of Prosopis juliflora to productive cultivation 


\section{Conclusion}

The study reports the benefits that are accrued due to assets of MGNREGA public works. The results confirm that MGNREGA assets are successfully aiding for improving sustainable living and exhibits positive impact on the natural resources. Activities like water conservation and water harvesting have resulted in facilitating irrigation and drinking water in the study area. Renovation process of traditional water bodies and water harvesting structures have led to increased water availability and hence increase in area under irrigated crop production. Most of the minor irrigation tanks have been de-silted and restored to their original capacity. The results of this flagship scheme have ushered green revolution and blue revolution in this part of the study area.

The root cause of rural poverty in India can be attributed to the water crisis, low crop production, soil erosion and land degradation, livestock problems, climatic calamities, non-availability of alternative income, and etc. Ungoverned land management practices will degrade natural resources. (Tiwari et al. 2011) suggested that rural sustainability can be achieved by conserving natural resources through locally evolved norms. One of the priorities of MGNREGA is to protect natural resources and achieve sustainability. Sustainable livelihood improvement programs will reduce dependency on natural resources.

In MGNREGA, the decision to implement the local activity is addressed by analyzing the problem faced by the community with the participation and co-operation of local authorities. As the level of governance is very close to grass-root level, the purpose of the assets is realized successfully. MGNREGA program may be a tool for human resource development but the spin-offs from this program have resulted sustainable livelihood in the rural areas of India. In the current study, it is observed that MGNREGA promoted the betterment of overall sustainability; it includes sustainability of agriculture, economy, forest conservation, and along with alternative income generation. The Ministry of Rural Development (MoRD), GoI has selected Vizianagaram as one among the 17 districts across the nation for the MGNREGA annual award for effective implementation of the program (Vizianagaram, 2017). In a recent report by (Kumara Charyulu, Moses Shyam, Wani, \& Raju, 2016) mentioned that there is ample scope for productivity levels and excellent opportunities for the agriculture sector in Vizianagaram district.

The study elaborates that the public works under MGNREGA are giving the positive results in all three dimensions of SD in the form of durable rural infrastructure in the dimension of society, enhances the sustainable eco-restoration process for the environmental dimension, and spend-ability by rural section improves the economic dimension at the national scale. The study demonstrated the usage of geospatial technology to assess the benefits that are accrued in terms of environment and socio-economic levels from the public works of MGNREGA.

\section{Acknowledgements:}

Deep gratitude is expressed by the authors to Dr.Santanu Chowdhury, Director, National Remote Sensing Centre, Hyderabad, India for his valuable guidance and also for providing facilities to carry out this study. We would also like to show our gratitude to Dr. Kamran Rizvi, Joint Secretary, Ministry of Rural Development, Government of India for his inspirable vision and providing an open platform for MGNREGA project in Internet which enabled to conduct this type of study. The authors are indebted to Dr. N Yogeswara Sastry, Director, Directorate of Economic \& Statistics, Government of Andhra Pradesh and Dr. S. Srinivasa Rao, General Manager, RRSC (West), Jodhpur, India for helping in formulating this work

\section{References}

AAAS. (2018). What are Geospatial Technologies. Retrieved from https://www.aaas.org/programs/scientific-responsibility-human-rights-law/overview-geospatial-project

Agri-Stat.

(2010).

Retrieved

from https://desap.cgg.gov.in/jsp/social/agriculture\%20at\%20a\%20glance\%202009-2010.pdf

Agri-Stat.

(2011).

Retrieved

from https://desap.cgg.gov.in/jsp/social/agriculture\%20at\%20a\%20glance\%202010-11.pdf

Agri-Stat.

(2012).

Retrieved

from https://desap.cgg.gov.in/jsp/social/agriculture\%20at\%20a\%20glance\%202011-12.pdf

Agri-Stat.

(2013).

Retrieved

from https://desap.cgg.gov.in/jsp/social/agriculture\%20at\%20a\%20glance\%202012-13.pdf

Agri-Stat.

(2014)

Retrieved

from https://desap.cgg.gov.in/jsp/social/agriculture\%20at\%20a\%20glance\%202013-14.pdf 
Agri-Stat.

(2015)

Retrieved

from

https://desap.cgg.gov.in/jsp/social/agriculture\%20at\%20a\%20glance2014-15.pdf

Agri-Stat. (2016). Retrieved from https://desap.cgg.gov.in/jsp/pdf/ASAG2015-16.pdf

Agri-Stat.

Retrieved

from https://desap.cgg.gov.in/jsp/social/agriculture\%20at\%20a\%20glance\%202016-2017.pdf

Allen, P. (1999). Reweaving the food security safety net: Mediating entitlement and entrepreneurship. Agriculture and human values, 16(2), 117-129.

Basiago, A. D. (1998). Economic, Social, and Environmental Sustainability in Development theory and urban planning practice. Environmentalist, 19(2), 145-161.

Beegle, K., Coudouel, A., \& Monsalve, E. (2017). Realizing the Full Potential of Social Safety Nets in Africa. World Bank, Washington, DC.

Bello, O. M., \& Aina, Y. A. (2014). Satellite remote sensing as a tool in disaster management and sustainable development: towards a synergistic approach. Procedia - Social and Behavioral Sciences, 120, 365-373. https://doi.org/10.1016/j.sbspro.2014.02.114

Bhatt, U. S., Walker, D. A., Raynolds, M. K., Bieniek, P. A., Epstein, H. E., Comiso, J. C. ... Zhang, J. (2017). Changing seasonality of panarctic tundra vegetation in relationship to climatic variables. Environmental Research Letters, 12(5). https://doi.org/10.1088/1748-9326/aa6b0b

Bose, N. (2017). Raising consumption through India's national rural employment guarantee scheme. World Development, 96, 245-263. https://doi.org/10.1016/j.worlddev.2017.03.010

Burgan, R. E., \& Hartford, R. A. (1993). Monitoring vegetation greenness with satellite data. General Technical Report INT-297. Ogden, UT: US Department of Agriculture, Forest Service, Intermountain Research Station (13).

Campagna, M. (2005). GIS for sustainable development. CRC Press, Boca Raton.

Dashboard. (2019). Retrieved from http://mnregaweb4.nic.in

Desai, S., Vashishtha, P., \& Joshi, O. (2015). Mahatma Gandhi National Rural Employment Guarantee Act: A Catalyst for Rural Transformation. National Council of Applied Economic Research (7259), New Delhi.

DESAP. (2019). Retrieved from https://desap.cgg.gov.in/

Devuyst, D. (2000). Linking impact assessment and sustainable development at the local level: the introduction $\begin{array}{llll}\text { of sustainability assessment systems. Sustainable development, } & 8(2), & \text { 67-78. }\end{array}$ https://doi.org/10.1002/(SICI)1099-1719(200005)8:2<67::AID-SD131>3.0.CO;2-X

Esteaves, T., Rao, K. V., Sinha, B., \& Roy, S. S. (2013). Environmental Benefits and Vulnerability Reduction Through Mahatma Gandhi NREGS: A Synthesis Report. Ministry of Rural Development, Government of India and Deutsche GIZ, New Delhi.

Gaetano, R., Ienco, D., Ose, K., \& Cresson, R. (2018). MRFusion: A Deep Learning architecture to fuse PAN and MS imagery for land cover mapping. arXiv preprint arXiv:1806.11452.

Gehrke, E., \& Hartwig, R. (2018). Productive effects of public works programs: What do we know? What should we know? World Development, 107, 111-124. https://doi.org/10.1016/j.worlddev.2018.02.031

GeoMGNREGA Dashboard. (2018). Retrieved from https://bhuvan-app2.nrsc.gov.in/mgnrega/nrega_dashboard_phase2/

Giribabu, D., Mohapatra, C., Reddy, C. S., \& Prasada Rao, P. V. V. (2019). Holistic Correlation of World's Largest Social Safety Net and its Outcomes with Sustainable Development Goals. International Journal of $\begin{array}{lllll}\text { Sustainable Development } \quad \& \quad \text { World } & \text { Ecology, }\end{array}$ https://doi.org/10.1080/13504509.2018.1519492

Grosh, M.E., Del Ninno, C., Tesliuc, E., \& Ouerghi, A. (2008). For protection and promotion: The design and implementation of effective safety nets. The World Bank. Washington, DC.

Indian Planning Commission. (2007). Eleventh Five Year Plan. Government of India. OUP, New Delhi. Vol. III.

ISRO. (2016). Retrieved from https://www.isro.gov.in/isros-geo-portal-bhuvan-gateway-to-indian-earth-observation

Kumara Charyulu, D., Moses Shyam, D., Wani, S. P., \& Raju, K.V. (2016). Rythu Kosam: Andhra Pradesh 
Primary Sector Mission. Baseline Summary Report. Research Report ICRISAT Development Centre, Research Report Number 11, Hyderabad, Telangana, India.

Lautenbacher, C. C. (2006). The global earth observation system of systems: Science serving society. Space Policy, 22(1), 8-11. https://doi.org/10.1016/j.spacepol.2005.12.004

Longley, P. A., Goodchild, M. F., Maguire, D. J., \& Rhind, D. W. (2005). Geographic information systems and science. John Wiley \& Sons, The Artium, Southern Gate, Chichester, West Sussex, England.

Maiorano, D., Das, U., \& Masiero, S. (2018). Decentralisation, Clientelism and Social Protection Programmes: A study of India's MGNREGA. Oxford Development Studies, 1-14.

MGNREGA Dashboard. (2018). Retrieved from http://mnregaweb4.nic.in/netnrega/nrega-reportdashboard/

MGNREGA Guide. (2019). Master Circular - A Guide for Programme Implementation FY 2018-2019. Retrieved from http://nrega.nic.in/Netnrega/WriteReaddata/Circulars/AMC_2018-19_nk_v3_21.03.18.pdf

Narain, P., Rai, S. C., \& Bhatia, V. K. (1999). Inter district variation of development in southern region. Journal of the Indian Society of Agricultural Statistics, 52, 106-120.

Nayyar, R. (2005). Planning for the Development of Backward Districts (2005). Chronic Poverty Research Centre Working Paper. https://dx.doi.org/10.2139/ssrn.1756833

NREGA Web Portal. (2019). Retrieved from http://nrega.nic.in

Odum, H. T. (2007). Environment, power and society. Columbia University Press. New York.

Paganini, M., \& Petiteville, I. (2018). Satellite Earth Observations in Support of the Sustainable Development Goals. European Space Agency.

Raju, N. A. (2015). Land capability and suitability in Vizianagaram district of Andhra Pradesh using remote sensing and GIS techniques. IOSR Journal of Humanities and Social Science, 20(7), 56-64.

Ranaware, K., Das, U., Kulkarni, A., \& Narayanan, S. (2015). MGNREGA Works and their impacts. Economic \& Political Weekly, 50(13).

Rao, S. N. (2014). Economic restructuring programme: Naidus developmental experiment in Andhra Pradesh, 1995 to 2001. Centre for Political Studies, Jawaharlal Nehru University.

Raubal, M. (2018). Cognition and geographic information technologies. In D. R. Montello (Ed.), Handbook of Behavioral and Cognitive Geography. Edward Elgar Publishing, Northampton, MA, USA.

Reddy, C. S. (2013). Innovation, Transparency and Governance: A Study of NREGS in Andhra Pradesh. Journal of Rural Development, 32(2),107-120.

Reddy, R. S., Nalatwadmath, S. K., \& Krishnan, P. (2005). Soil Erosion Andhra Pradesh. National Bureau of Soil Survey and Land Use Planning, Publication No. 114, Nagpur, India.

Rockström, J., \& Sukhdev, P. (2016). How food connects all the SDGs. Stockholm Resilience Centre. Retrieved from

http:/www.stockholmresilience.org/research/research-news/2016-06-14-how-food-connects-all-the-sdgs.ht $\mathrm{ml}$

Sage, C. (2011). Environment and food. Routledge.

Shakoor, A., Shehzad, A., \& Asghar, M. N. (2006). Application of remote sensing techniques for water resources planning and management. In Advances in Space Technologies, 2006. International Conference on pp. 142-146. IEEE. 2006.

Singh, R. K., Murty, H. R., Gupta, S. K., \& Dikshit, A. K. (2009). An overview of sustainability assessment methodologies. Ecological indicators, 9(2), 189-212. https://doi.org/10.1016/j.ecolind.2008.05.011 .

Subbarao, K., Del Ninno, C., Andrews, C., \& Rodríguez-Alas, C. (2012). Public works as a Safety Net: Design, Evidence, and Implementation. The World Bank, Washington, DC.

Tiwari, R. et al. (2011). MGNREGA for Environmental Service Enhancement and Vulnerability Reduction: Rapid Appraisal in Chitradurga district, Karnataka. Economic \& Political Weekly, 46(2).

United Nations. (2015). Transforming our world: The 2030 agenda for sustainable development. Resolution adopted by the General Assembly. Retrieved from http://www.un.org/ga/search/view_doc.asp?symbol=A/RES/70/1\&Lang=E 
Verma, S., \& Shah, T. (2012). Beyond Digging and Filling Holes: Lessons from Case Studies of Best-performing MGNREGA Water Works. IWMI-Tata Water Policy Programme. Retrieved from http://www.iwmi.cgiar.org/iwmi-tata/ PDFs/2012_Highlight-42.pdf

Vizianagaram Details. (2017). District Profile of Vizianagaram. Retrieved from http://apedb.gov.in/about-vizianagaram-district.html

Vizianagaram. (2017). Vizianagaram bags MGNREGA national award. Retrieved from https://www.thehindu.com/news/national/andhra-pradesh/vizianagaram-bags-mgnrega-national-award/articl e18713659.ece

Wackernagel, M., \& Rees, W. (1998). Our ecological footprint: reducing human impact on the Earth (Vol. 9). New Society Publishers.

WBIS. (2019). Water Body Information System (WSBI). Retrieved from http://bhuvan.nrsc.gov.in/gis/thematic/wbis

World Bank. (2015). The State of Social Safety Nets 2015. Wold Bank. Washington, DC.

World Bank. (2017). Closing the gap: The State of Social Safety Nets - 2017. Washington, D.C.: World Bank Group.

Retrieved

from http://documents.worldbank.org/curated/en/811281494500586712/Closing-the-gap-the-state-of-social-safet y-nets-2017

\section{Copyrights}

Copyright for this article is retained by the author(s), with first publication rights granted to the journal.

This is an open-access article distributed under the terms and conditions of the Creative Commons Attribution license (http://creativecommons.org/licenses/by/4.0/). 